\title{
Comparative Study of Mild Steel Corrosion Inhibition of Piper Guineense Leaves Extract and Vernonia Amygdalina Leaves Extract in Concentrated Corrosive Medium
}

\author{
N. E. Ibisi, D. O. Okoroafor, C. C. Amuta \\ Department of Chemistry, College of Physical and Applied Sciences, Michael Okpara University of Agriculture \\ Umudike, P.M.B 7267 Umuahia, Abia-State. Nigeria.
}

\begin{abstract}
The inhibitory behavior of Piper guineense leaves extract and Vernonia amygdalina leaves extract on corrosion of mild steel in $2.5 \mathrm{M} \mathrm{HCl}$ solution, are comparatively studied using gravimetrical and gasometrical methods respectively. The results obtained showed that both Piper guineense leaves extract and Vernonia amygdalina leaves extract efficiently inhibit corrosion of mild steel in concentrated corrosive medium. The inhibition efficiency increased with increase in the extract concentration but decreased with rise in temperature. Both plant extracts showed almost $100 \%$ inhibition efficiency at concentration of $0.5 \mathrm{~g} / \mathrm{l}$. The corrosion inhibition properties of the two plant extracts is attributed to adsorption of the phytochemical molecules on the surface of the mild steel creating a barrier between the mild steel and the corrosive solution, and the adsorption of the extracts fitted into Langmuir adsorption isotherm. A study of the trends in thermodynamic parameters like activation energy and heat of adsorption indicated that both Piper guineense leaves and Vernonia amygdalina leaves extracts were physically adsorbed to the metal surface, and the reaction was spontaneous and exothermic.
\end{abstract}

Key Words: Piper guineense, Vernonia amygdalina, Corrosion inhibition, Adsorption, Physisorption.

\section{Introduction}

Most metals in pure form are thermodynamically unstable, this is due to the high energy content of the elements in metallic form, and as such most metals used in construction of facilities are subjected to corrosion. Naturally, most metals exist chemically in combined form with other elements, but for them to be suitable for industrial applications they are refined to form pure metals and alloys. As the energy content of the metals and alloys in pure state, is greater than that of their ores, chemical combination of the metals to form ore-like compounds becomes spontaneous process.

Corrosion of metals takes place through the action of electrochemical cells, although this single mechanism is responsible in corrosion, corrosion of metals can takes many forms. Through an understanding of the electrochemical cell and how it can act to cause the various forms of corrosion, the natural tendency of metals to suffer corrosion can be overcome. ${ }^{[5]}$

In virtually all situations, metal corrosion can be managed, slowed, or even stopped by using the proper techniques. Corrosion prevention can take a number of forms depending on the circumstances of the metal being corroded. The rate of corrosion of metals can be controlled by reducing the aggressiveness of the medium, or by isolating the metals from the liquid. The latter can be done by coating the metal with a millimeter thick impervious non corroding material. These have wide spread use, but their effect may not be permanent because of brakes in the coating over time. Also in some systems coating might interfere with the process for which the equipment is used, they might change the heat transfer properties for example. The use of corrosion inhibitors proffers a better solution to the problem. ${ }^{[5 \& 13]}$

\subsection{CORROSION INHIBITOR}

A study of published research results has proved the effectiveness of using inhibitors to retard corrosion. ${ }^{[1-6,13-19] .}$ Corrosion inhibitors are chemicals that react with the metal surface or the environmental gasses causing corrosion, thereby, interrupting the chemical reaction that causes corrosion. Inhibitors can work by adsorbing themselves on the metal surface, forming a protective film. These chemicals can be applied as a solution or as a protective coating via dispersion techniques.

The inhibitors process of slowing corrosion depends upon:

- Changing the anodic or cathodic polarization behavior

- Decreasing the diffusion of ions to the metal's surface

- Increasing the electrical resistance of the metal's surface

Major end-use industries for corrosion inhibitors are petroleum refining, oil and gas exploration, chemical production and water treatment facilities. 
The benefit of corrosion inhibitors is that they can be applied in-situ to metals as a corrective action to counter unexpected corrosion. ${ }^{[12]}$

The inhibitors may be organic or inorganic compounds. Inorganic substances such as phosphates, chromates, dichromates and arsenates have been found to be effective inhibitors of metal corrosion, but a major disadvantage is their toxicity and as such their use has come under severe critics. In alternative, organic corrosion inhibitors have been widely applied in solving corrosion problems because of their availability and ease of application. Organic corrosion inhibitors are usually composed of hetero-atoms such as N, S, and $\mathrm{O}$ in conjugate systems, with which they get absorbed to the metal surface. ${ }^{[2-6]}$. In contrary, some synthesized organic inhibitors could be hazardous to life which limits the choice of synthesized organic inhibitors as a solution. The current growing trend in bio-technology has geared many researchers towards discovering natural metal corrosion inhibitors of plants source which are in-expensive, readily available, renewable, environmentally friendly and ecologically acceptable. ${ }^{[5]}$

It is reported in Abiola, ${ }^{[20]}$ that the corrosion inhibition properties in many plants extracts is due to their heterocyclic constituents like alkaloids, tannins, flavonoids, phenols, saponins steroids etc. Again it is suggested that medicinal plants exhibit good corrosion inhibiting properties, because they are mostly constituted of compounds containing hectero-atoms like $\mathrm{O}, \mathrm{N}, \mathrm{S}$, and $\mathrm{P}$ which are reported to have corrosion inhibiting properties. ${ }^{[2-6,21-23]}$. Owing to the medicinal values of Piper guineense and Vernonia amygdalina plants we suggest it will possess good corrosion inhibition properties.

\subsection{PLANT DESCRIPTION AND USAGE}

Piper guineense is climbing vine that can grow up to $20 \mathrm{~m}$ in length. It is native to tropical regions of central and Western African and is Semi- cultivated in countries such as Nigeria where the leaves (known as Uziza) are used as a flavoring for stews and soup. Like other members of the pepper family. Piper guineense contain 5-8\% of the chemical significant proportion (10\%) of myristicin, elemicin, safrole and dillapoil.

In terms of flavor, the seed is very similar is cubeb pepper but is much less bitter and has a fresher more herbaceous flavor. Though known in Europe during the Middle Ages (it was a common spice is Roven and Dieppe in $14^{\text {th }}$ century, France), these days the use is marginalized of west and central African. ${ }^{[25]}$

Piper guineense leaf is reported to contain phytochemicals like, alkaloids tannins, saponins, flavonoids, ${ }^{[26]}$ tarponoid, phlobatanins, ${ }^{[25]}$, resins, ${ }^{[27]}$ and essential oil. ${ }^{[28]}$. Piper guineense leaves are considered aperitif, carminative and eupeptic ${ }^{[29]}$. They are used to treat respiratory infections, rheumatism, and syphilis ${ }^{[30]}$. In Nigeria, the leaves have been shown to have antibacterial activity. ${ }^{[31]}$. Piper. guineense leaves are aseptic in nature and have the ability to relieve flatulence. ${ }^{[32]}$ They are also used for treating female infertility and low sperm count in male. ${ }^{[33]}$

Vernonia amygdalina, commonly known as bitter leaf, is a shrub that grows up to 3 meters high in the African tropics and other parts of Africa, particularly, Nigeria, Cameroon and Zimbabwe. It is reputed to have several health benefits. The organic fraction extracts of the plant was shown to possess cytotoxic effects towards human carcinoma cells of the nasopharynx. ${ }^{[34]}$ It is effective against amoebic dysentery [35], gastrointestinal disorders, [36], and has antimicrobial and antiparasitic activities. ${ }^{[37 \& 38]}$ The phytochemicals compounds of Vernonia amygdalina are saponins and alkaloids, ${ }^{[39]}$, terpenes, steroids, coumarins, flavonoids, phenolic acids, lignans, xanthones and anthraquinone ${ }^{[40]}$, edotides ${ }^{[41]}$ and sesquiterpenes. ${ }^{[34]}$.

Owing to the phytochemical constituents and medicinal properties of Piper guineense leaves and Vernonia amygdalina leaves we suggest they will possess good corrosion inhibition properties. This study investigates comparatively the inhibitory effect of Piper guineense leaves extract and Vernonia amygdalina leaves extract on corrosion of mild steel in $2.5 \mathrm{M} \mathrm{HCl}$ solution using gravimetric and gasometrical techniques.

\subsection{MATERIALS}

\section{Materials And Methods}

The materials used for the study were mild steel sheet. The weight composition of the mild steel is recorded in table blow.

Table1: Weight composition of mild steel

\begin{tabular}{llllll}
\hline Element & $\mathrm{C}$ & $\mathrm{M} \mathrm{n}$ & $\mathrm{P}$ & $\mathrm{S} \mathrm{i}$ & $\mathrm{Fe}$ \\
\hline Weight (\%) & 0.15 & 0.6 & 0.36 & 0.03 & 98.86 \\
\hline
\end{tabular}

The mild steel sheet was obtained from metallurgical department federal university of technology Owerri Imo state Nigeria. For the purpose of this study the mild steel sheet was mechanically pressed cut to form different coupons, each of dimension $2 \mathrm{~cm} \mathrm{X} 2 \mathrm{~cm} \mathrm{X} 0.1 \mathrm{~cm}$. Each coupon was degreased by washing with ethanol, dried in acetone and preserved in desiccators prior to use. All reagents used for the study were analar grade and double distilled water was used for their preparation. 


\subsection{EXTRACT PREPARATION}

Vernonia amygdalina and Piper guineense leaves were collected from plants around Michael Okpara University of Agriculture Umudike Abia State Nigeria. The leaves were cut into pieces to increase the surface area for easy drying. The piecesed leaves were then oven dried with laboratory oven at $50^{\circ} \mathrm{C}$. The drying and every other analysis were carried out in chemistry Lab, College of physical and applied sciences, Michael Okpara University of Agriculture Umudike. The dried leaves samples each were ground to powder form, and extracted for $72 \mathrm{hrs}$. Then the extracts were evaporated to dryness and from the resultant dried concentrate of the samples (Vernonia amygdalina and Piper guineense) extract test solutions of $0.1 \mathrm{~g} / \mathrm{l}, 0.2 \mathrm{~g} / \mathrm{l}, 0.3 \mathrm{~g} / \mathrm{l}$ and $0.5 \mathrm{~g} / \mathrm{l}$ were prepared in $2.5 \mathrm{M} \mathrm{HCl}$ solutions.

\subsection{GRAVIMETRIC ANALYSIS (WEIGHT LOSS)}

Weight loss experiment were conducted under total immersion conditions in $250 \mathrm{ml}$ of test solutions maintained at $30^{\circ} \mathrm{C}, 40^{\circ} \mathrm{C}, 50^{\circ} \mathrm{C}$ and $60^{\circ} \mathrm{C}$ respectively. The test coupons were retrieved at the end of immersion period, scrubbed with bristle brush under running water until clean. The clean test coupons which were weighed before immersion were then dried in acetone and reweighed. The weight loss therefore was obtained as the difference between weight of coupons before and after immersion, from the weight loss data corrosion rate of the mild steel was calculated using equation 2.1

$\mathrm{CR}=\frac{\Delta w t}{A t}$

Where $C R$ represents corrosion rate, $A$ is surface area of the coupon, $\mathrm{t}$ is the time of immersion and $\Delta w t$ is change in weight (weight loss)

With the calculated values of corrosion rate of the mild steel in test solutions containing Piper guineense extract and Vernonia amygdalina extract respectively and corrosion rate of the coupon in uninhibited system (blank), the inhibition efficiency and degree of surface coverage of the plant extract molecules were calculated using equation 2.2 and 2.3 .

$$
\begin{aligned}
& \theta=1-\frac{C R_{i n}}{C R_{b l}} \ldots \\
& I E=\left(1-\frac{C R_{i n}}{C R_{b l}}\right) X 100 \ldots
\end{aligned}
$$

Where $C R_{i n}$ and $C R_{b l}$ are corrosion rates in inhibited test solution and uninhibited system (blank) respectively, $\theta$ is degree of surface coverage while $I E$ is inhibition efficiency.

\subsection{GASOMETRIC METHOD}

Gasometrical analyses were carried out at $30^{\circ} \mathrm{C}$ for $1 \mathrm{hrs}, 40^{\circ} \mathrm{C}$ for $30 \mathrm{~min}, 50^{\circ} \mathrm{C}$ for $15 \mathrm{~min}$ and $60^{\circ} \mathrm{C}$ for $10 \mathrm{~min}$. From the volume of hydrogen gas evolved per minute degree of surface coverage $(\theta)$ and inhibition efficiency were calculated using equation $2.4 \& 2.5 .^{[1,2,3 \& 4]}$

$$
\begin{gathered}
\theta=\left(1-\frac{V_{H t}^{1}}{V_{H t}^{0}}\right) \ldots \\
I E(\%)=\left(1-\frac{V_{H t}^{1}}{V_{H t}^{0}}\right) X 100
\end{gathered}
$$

Where, $V_{H t}^{1}$ is the volume of hydrogen evolved at time $t$ for inhibited solution and $V_{H t}^{o}$ is the volume in uninhibited solution, $I E$ and $\theta$ stand for inhibition efficiency and degree of surface coverage respectively.

\subsection{GRAVIMETRIC RESULTS}

\section{Results And Discussion}

The mild steel corrosion inhibition behavior of Vernonia amygdalina leaves extract and Piper guineense leaves extract each and respectively in $2.5 \mathrm{M} \mathrm{HCl}$ studied gravimetrically are represented graphically in the figures 1 and 2. Observations from the figures showed decrease in weight loss in the corrosive solution containing both plants extracts from what was observed in the blank corrosive solution without the extracts. This indicates a decrease in corrosion rate as Vernonia amygdalina leaves extract and Piper guineense leaves extract were introduced into the corrosive medium. It can as well be observed that, as the concentration of the plants (Piper guineense leaves and Vernonia amygdalina leaves) extracts increased from $0.1 \mathrm{~g} / 1$ to $0.5 \mathrm{~g} / 1$ the decrease in corrosion rate became more pronounced, and so pronounced that the corrosion rates of mild still coupons in $2.5 \mathrm{M} \mathrm{HCl}$ solution containing Piper guineense leaves extract and Vernonia amygdalina leaves extract (separately and respectively) were almost zero in $0.5 \mathrm{~g} / \mathrm{l}$ extracts concentrations. These observations affirm corrosion inhibition of the test coupons by the Vernonia amygdalina leaves extract and Piper guineense leaves extract. 


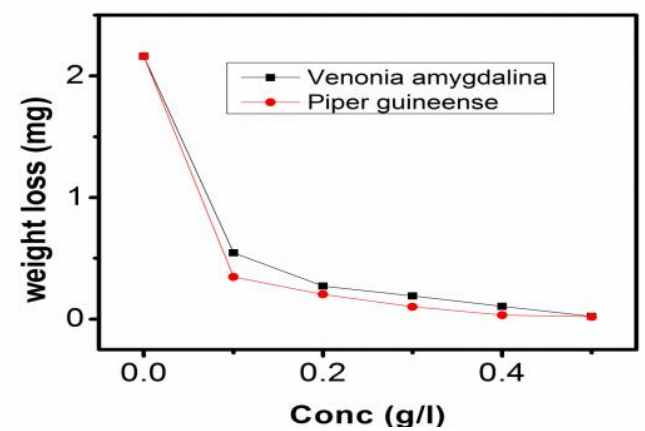

Figure 1: Gravimetrically determined plot of weight loss against conc.

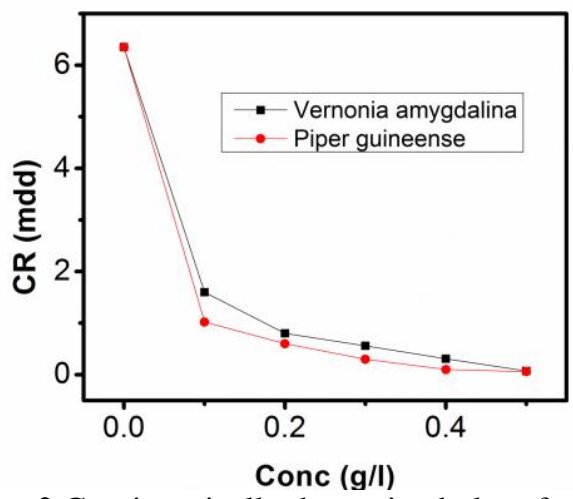

Figure 2 Gravimetrically determined plot of corrosion rate against conc.

The extent of corrosion inhibition of Piper guineense leaves extract and Vernonia amygdalina leaves extract on corrosion of mild steel in corrosive medium studied, is known by studying the relationship between extract concentration and inhibition efficiency of the extract on the mild steel coupon. Figure 3 shows a plots of inhibition efficiency against concentration Piper guineense leaves extract and Vernonia amygdalina leaves extract. Observations from the graphs show that inhibition efficiencies of both plants extracts increase as the concentrations of the plants extracts increase in $2.5 \mathrm{M} \mathrm{HCl}$ solution. Interestingly, the inhibition efficiencies of both plants (Piper guineense and Vernonia amygdalina) leaves extracts at $0.5 \mathrm{mg} / 1$ concentration of the extracts concentration were almost $100 \%$, which shows that the leaves extracts of the two plants can be perfect corrosion inhibitors.

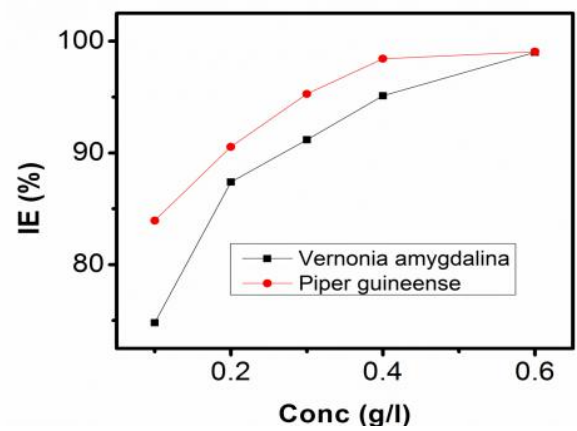

Figure 3: Gravimetrically determined plot of inhibition efficiency against conc.

\subsection{GASOMETRIC RESULTS}

The results of gasometrical analysis of mild steel corrosion inhibition in extreme corrosive medium (2.5M HCl solution) by Piper guineense leaves extract and Vernonia amygdalina leaves extract each and respectively, are graphically represented in figure 4 and 5. Figure 4 is plots of volume of hydrogen gas evolved against concentrations of the plant (Piper guineense and Vernonia amygdalina) leaves extracts, and figure 5 is the plots of corrosion rates of mild steel coupons in $2.5 \mathrm{M} \mathrm{HCl}$ blank solution and the ones containing Piper guineense leaves extract and Vernonia amygdalina leaves extract each and respectively.. A study of the figures reveals that corrosion rates decreased in the presence of the inhibitors (Piper guineense leaves extract and 
Vernonia amygdalina leaves extract) from the result observed from the blank $2.5 \mathrm{M} \mathrm{HCl}$ solution. The reduction in corrosion rate became more pronounced as the concentration of the extract increased from $0.1 \mathrm{~g} / \mathrm{l}$ to $0.5 \mathrm{~g} / \mathrm{l}$. This is an evidence of corrosion inhibition as more extract molecules are introduced into the system. This marked decrease in corrosion rate indicates that the plants extracts inhibited corrosion of mild steel in the acid medium studied with marked inhibition efficiency.

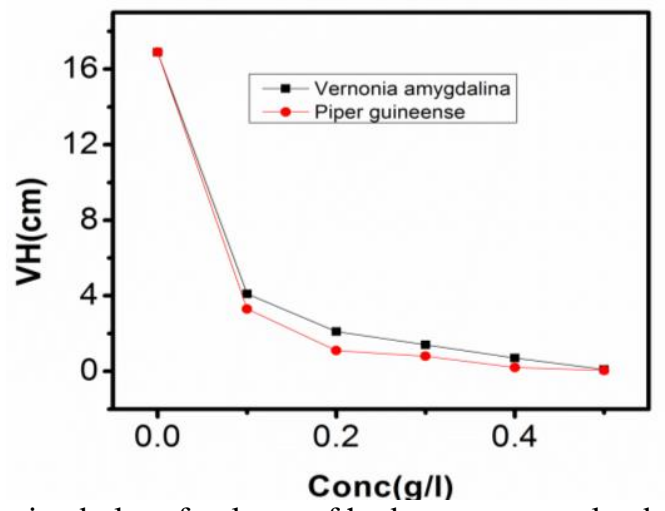

Figure 4: Gasometrical determined plot of volume of hydrogen gas evolved against concentration of plant extract.

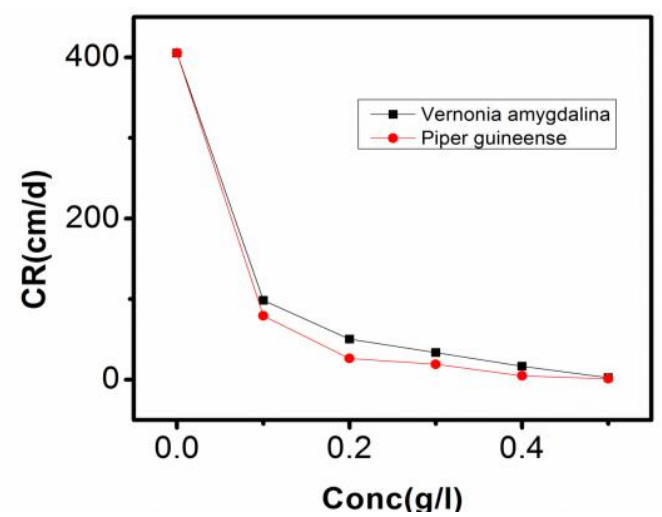

Figure 5: A plot of Gasometrical Determined Corrosion rate against Concentration.

Inhibition efficiencies of Piper guineense leaves extract and Vernonia amygdalina leaves extract respectively increased as the concentrations of the test samples extracts increased from $0.1 \mathrm{~g} / \mathrm{l}$ to $0.5 \mathrm{~g} / \mathrm{l}$ as shown in figure 6. This indicates that the more the extract molecules are added to the system the more corrosion is being inhibited. The inhibition abilities of the Piper guineense and Vernonia amygdalina can be attributed to the extract molecules getting absorbed to the surface of the mild steel thereby creating a barrier between the material and the acid. ${ }^{[5,6]}$. Mean while, a cross examination of the results obtained from the gravimetric analysis and gasometrical analysis shows that the results are all closely related which proves evidence of corrosion inhibition.

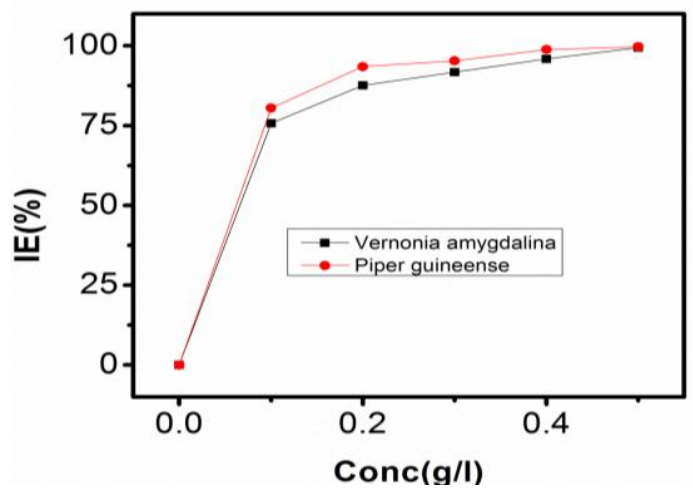

Figure 6: Gasometrical determined plot of inhibition efficiency against Concentration of plant extract studied. 


\subsection{ADSORPTION BEHAVIOR}

The inhibitory effect of the plant extract is due to extract phytochemical molecules getting absorbed to the surface of the mild steel to form a film layer on the interface, preventing the corrodent from having direct contact with the metal, and thereby inhibiting corrosion. The relationship between the degree of surface coverage of $(\theta)$ Vernonia amygdalina and Piper guineense extracts can be represented by the Langmuir adsorption isotherm, as stated in equation 3.1.

$$
(1+x)^{n} \theta=C+\frac{1}{K_{a d}} \ldots
$$

Where $K$ is the constant for adsorption related to the free energy $\left[\Delta G_{a d}^{O}\right.$ ] by the relation in equation 3.2

$$
K=\frac{1}{55.5} \exp \left(\frac{\left(\Delta G_{a d}^{0}\right)}{R T}\right) \ldots
$$

Figure 7 and 8 show the plots of $\frac{\mathrm{C}}{\theta}$ against concentration of leaves, extracts of Vernonia amygdalina and Piper guineense leaves extracts in $2.5 \mathrm{M} \mathrm{HCl}$ gravimetrically and gasometrical studied to be linear, with intercept $\frac{1}{K}$ which suggest that the experiment fitted into Langmuir adsorption isotherm. The calculated values $\Delta G_{a d}$ are shown in table 2 and 3, from the results in the tables it can be observed that the values are all negative which indicates that Vernonia amygdalina and Piper guineense leaves extracts were spontaneously adsorbed to the surface of the mild steel in concentrated acid medium studied without any inducement . [5]

Table 2: Results of gravimetrically Determined Free Energy of Adsorption of Piper guineense and Vernonia amygdalina

\begin{tabular}{lll}
\hline System $(\mathrm{g} / \mathrm{l})$ & Vernonia amygdalina $\Delta G_{a d}^{o}(\mathrm{KJ})$ & Piper guineense $\Delta G_{a d}^{o}(\mathrm{KJ})$ \\
\hline 0.1 & -1.26 & -2.68 \\
0.2 & -1.65 & -2.46 \\
0.3 & -1.63 & -3.32 \\
0.4 & -2.51 & -5.45 \\
0.5 & -6.04 & -6.20
\end{tabular}

Table 3 Results of Gasometrical Determined Free Energy of Adsorption of Piper guineense and Vernonia amygdalina

\begin{tabular}{lll}
\hline Concentration $(\mathbf{g} / \mathbf{l})$ & $\Delta \boldsymbol{G}_{a d}^{\mathbf{0}}(\mathbf{K J})$ Vernonia amygdalina & $\Delta \boldsymbol{G}_{a d}^{\mathbf{0}}(\mathbf{K J})$ Piper guineense \\
\hline 0.1 & -34.82 & -37.62 \\
0.2 & -36.04 & -43.24 \\
0.3 & -36.51 & -42.54 \\
0.4 & -41.06 & -54.07 \\
0.5 & -23.00 & -65.76 \\
\hline
\end{tabular}

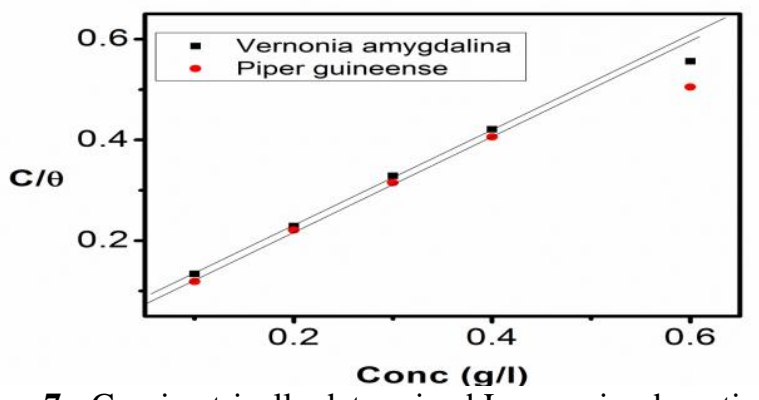

Figure 7: Gravimetrically determined Langmuir adsorption isotherm

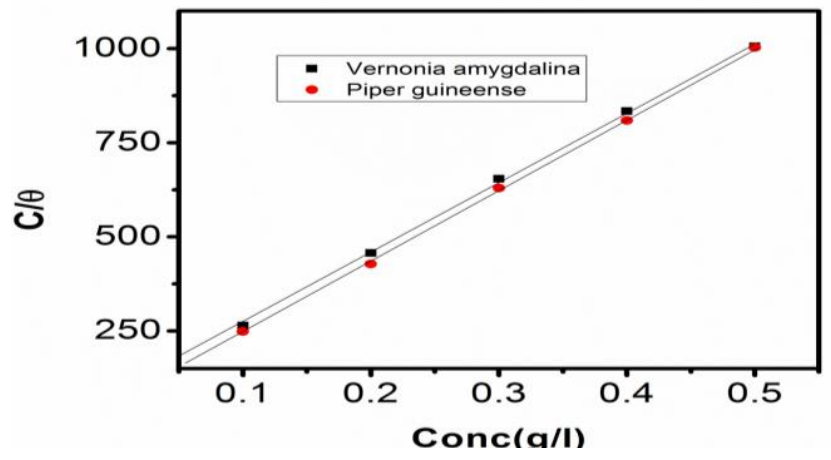

Figure 8: Gasometrically determined Langmuir adsorption isotherm 


\subsection{EFFECT OF TEMPERATURE}

Temperature has a significant influence on metal corrosion rates and inhibition efficiencies of corrosion inhibitor for when the corrosion reaction involves a cathodic process of hydrogen gas evolution, the corrosion rate increases exponentially wit rise in temperature according to Arrhenius type dependence and the inhibition efficiency decreases as temperature rises. Figure 9, illustrates the effect of temperature on inhibition efficiency of the Vernonia amygdalina and Piper guineense leaves extracts on corrosion of mild steel in $2.5 \mathrm{M} \mathrm{HCl}$ solution.

From the figure, inhibition efficiency in the two plant extracts studied (Vernonia amygdalina and piper guineense leaves) decreased with rise in temperature indicating evidence of physisorption. This observation can be explained with respect to the characteristic features of the cathodic process of hydrogen evolution where the increase in temperature leads to an increase in the rate of the cathodic reaction. ${ }^{[7,8]}$. This effect far overshadows the adsorption and inhibitive effect of Vernonia amygdalina and Piper guineense, because the enhanced rates of hydrogen gas evolution increasingly agitate the interface, which hinder inhibitor adsorption and also promotes dispersal of adsorbed inhibitor. ${ }^{[5,9,10]}$.

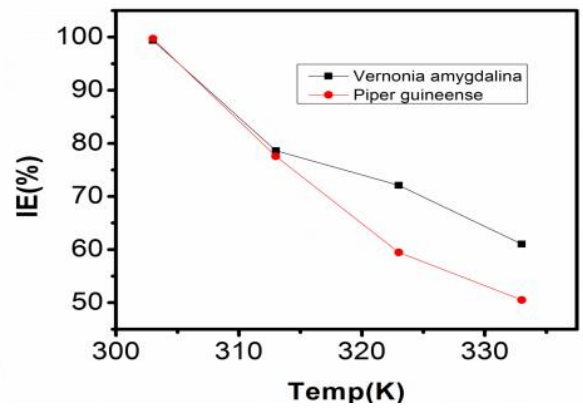

Figure 9: A plot of the inhibition efficiency of the plant extract against temperature of the system studied.

This marked decrease in inhibition efficiency with rise in temperature could be attributed to the shift of the adsorption desorption equilibrium towards desorption. This behavior suggests that Vernonia amygdalina and Piper guineense were physically adsorbed on the mild steel surface, ${ }^{[6,11]}$

The reaction between corrosion rate and temperature is often expressed by the Arrhenius equation in equation 3.3.

$\mathrm{K}=A \exp -\left(\frac{E a}{R T}\right)$

Where $E a$ is the activation energy of Arrhenius pre-exponential factor and $\mathrm{R}$ is the gas constant.

Equation 3.3 can be further expressed as the expression in equation 3.4.

$\log \frac{\mathrm{CR}_{2}}{\mathrm{CR}_{1}}=\frac{E a}{2.303 R T}\left(\frac{1}{T_{1}}-\frac{1}{T_{2}}\right) \ldots$

Where $C R_{1}$ and $C R_{2}$ are the corrosion rates at temperatures $T_{1}$ and $T_{2}$ respectively, other parameters retain their previous meaning. The apparent activation energies (Ea) for mild steel coupons in absence and presence of Vernonia amygdalina and Piper guineense were evaluated using equation 3.4 above. Activation energy is observed from table 4 to increase in inhibited systems containing extracts of Vernonia amygdalina and Piper guineense respectively. Such behavior coupled with a decrease in inhibition efficiency as temperature rises is evidence of physisorption interaction between the extract specie and mild steel surface. ${ }^{117,42 \& 43]}$

Another thermodynamic parameter which further describes the adsorption mechanism operative in the corrosion inhibition process is the heat of adsorption $\left(Q_{a d}\right)$. It is related to the surface coverage through the relation in equation 3.5

$\mathrm{Q}_{\mathrm{ad}}=2.303 R\left[\log \left(\frac{\theta_{2}}{1-\theta_{1}}\right)-\log \left(\frac{\theta_{1}}{1-\theta_{1} !}\right)\right] \times\left(\frac{1}{T_{1}}-\frac{1}{T_{2}}\right) \ldots$

Where $Q_{a d}$ is heat of adsorption $\theta_{1}$ and $\theta_{2}$ are degrees of surface coverage at temperatures $T_{1}$ and $T_{2}$ respectively. The calculated values of heat of adsorption shown in table 4 are all negative and in the range of $-7.04 \mathrm{X}^{10^{-7}}$ to $2.81 \mathrm{X} \mathrm{10}^{-7} \mathrm{Kjmol}^{-1}$ in Piper guineense leaves extracts and $-3.88 \times 10^{-7}$ to $-2.90 \times 10^{-7} \mathrm{Kjmol}^{-1}$ in Vernonia amygdalina leave extract. The negative values of heat of adsorption further indicate that adsorption was spontaneous and physisorptive in the two plant extracts studied. ${ }^{[5,6 \& 44-58]}$

Table 4.15: Results of Activation Energy and Heat of Adsorption of Piper guineense and Vernonia amygdalina

\begin{tabular}{llll}
\hline System & Ea $(\mathbf{K J}) \mathbf{3 0 3}-\mathbf{3 1 3 k}$ & $\mathbf{E a}(\mathbf{K J}) \mathbf{3 1 3}-\mathbf{3 2 3 k}$ & $\mathbf{E a}(\mathbf{K J}) \mathbf{3 2 3}-\mathbf{3 3 3 k}$ \\
\hline Blank & 93.93 & 85.17 & 39.01 \\
Vernonia amygdalina & 377.94 & 107.54 & 68.91 \\
Piper guineense & 436.76 & 134.21 & 57.48 \\
& $\mathbf{Q}_{\mathbf{a d}}$ & $\mathbf{Q}_{\mathbf{a d}}$ & $\mathbf{Q}_{\mathbf{a d}}$ \\
Vernonia amygdalina & $-3.34 \times 10^{-6}$ & $-2.90 \times 10^{-7}$ & $-3.88 \times 10^{-7}$ \\
\hline
\end{tabular}




\begin{tabular}{llll}
\hline Piper guineense & $-3.99 \times 10^{-6}$ & $-7.04 \times 10^{-7}$ & $-2.81 \times 10^{-7}$ \\
\hline
\end{tabular}

\section{Conclusion}

From the results of the study, the following conclusion were made,

1. Extracts of Piper guineense leaves and Vernonia amygdalina leaves extract each and respectively, effectively inhibited corrosion of mild steel in $2.5 \mathrm{M} \mathrm{HCl}$ solution.

2. The inhibitive effect resulted from adsorption of Vernonia amygdalina and Piper guineense extracts respectively on mild steel surface fitting into Langmuir adsorption isotherm

3. The inhibition efficiency of the two plants extracts Vernonia amygdalina and Piper guineense increased with extracts concentration but decrease with rise in temperature, suggesting physical absorption mechanism

4. The adsorption of ethanol extract of these inhibitors is strongly activated. The adsorption is also found to be spontaneous and exothermic.

\section{References}

[1]. Okafor, P.C., Osabor, V.I., and Ebenso, E.E., (2007), Eco-friendly corrosion inhibitors: inhibitive action of ethanol extracts of Garcinia kola for the corrosion of mild steel in $\mathrm{H}_{2} \mathrm{SO}_{4}$ solutions, Pigment\& Resin technology, 36(5): 299-305.

[2]. Umoren S.A., Obot I.B., Ebenso E.E., Okafor P.C., Ogbobe O., and Oguzie E.E (2006), Gum Arabic as a potential corrosion inhibitor for aluminium in alkaline medium and its adsorption characteristics, Anti-Corr Meth and Mater, 53 (5): $277-282$

[3]. Umoren S.A., Ebenso E.E., (2007), The synergistic effect of polyacrylamide and iodide ions on the corrosion inhibition of mild steel in $\mathrm{H}_{2} \mathrm{SO}_{4}$, Mater. Chem. Phys. 106, 2, 387-393.

[4]. Ibisi N. E., Okoroafor D. O. and Ogu C., (2015), Voacanga africana as green inhibitor of corrosion of mild steel in corrosive environment. Time Journals of Engineering and Physical Sciences., 3, 1:63-69.

[5]. Ibisi N.E., and Okoroafor D.O., (2016), Senna alata acid extract as eco-friendly corrosion inhibitor in acidic medium, International Journal for Research in Applied Chemistry, 2 (4): 15- 31

[6]. Ihebrodike M. Mejeha, Michael, C. Nwandu, Kelechukwu B. Okeoma, Lebe A.N, Maduabuchi A.C, Francis C.E, (2012) Experimental and theoretical assessment of the inhibiting action of Aspilia africana extract on corrosion of aluminium alloy AA3003 in hydrochloric acid, J Mater Sci 47:2559-2572

[7]. Harek, Y., Larabi, L., (2004), Corrosion inhibition of mild steel in $1 \mathrm{M} \mathrm{HCl}$ by Oxalic N-phenylhydrazide phenylthiosemicarbazide, Kem. Ind., 2, 53-55

[8]. Ibisi, N. E., and Uwakwue V. I., (2015), Cnestis ferruginea as eco-friendly corrosion inhibitor of mild steel in corrosive environment. Glob. J. of Env. Sci. and Tech, 2, 6:355-359.

[9]. Oguzie E.E, Wang S.G, Li Y, Wang F.H, (2009), Influence of iron microstructure on corrosion inhibitor performance in acidic media, J Phys Chem C. 113:8420-8429

[10]. Ibisi N. E. And Amadi S. O., (2016), Corrosion Inhibition of Mild Steel in HCl using

[11]. Methylene Blue as Inhibitor. International Journal of Research in Chemistry and Environment , 6 (1) 38-41

[12]. Popova, A.; Sokolova, E.; Raicheva, S.; Christov, M., (2003), AC and DC Study of the temperature effect on mild steel corrosion in acid media in the presence of benzimidazole derivatives. Corros. Sci., 45, 33- 58

[13]. Terence B.,(2016), methods for slowing or stoping corrosion, corrosionist .com http:wwwasp.org/database/custom/cprotenctioncorrsionprtection.pdf

[14]. Khaled K.F., Hackerman N., (2003), Investigation of the inhibitive effect of ortho-substituted anilines on the corrosion of iron in $0.5 \mathrm{M} \mathrm{H}_{2} \mathrm{SO}_{4}$, Mater. Chem. Phys., 82, 949

[15]. Oguzie, E.E., Li, Y., and Wang, F.H., (2007). Effect of surface nanocrystallization on corrosion and corrosion inhibition of low carbon steel: Synergistic effect of methionine and iodide ion, Electrochimica Acta, 53(24): 6988-6996.

[16]. Oguzie, E.E., Enenebeaku, C.K., Akalezi, C.O., Okoro, S.C., Ayuk, A.A., Ejike, E.N., (2010), Adsorption and corrosioninhibiting effect of Dacryodisedulis extract on low-carbonsteel corrosion in acidic media, Journal of Colloid and Interface Science, 349(1): 283-292

[17]. Obot, I.B.; Obi-Egbedi, N.O.; Umoren, S.A. (2009), drugs as corrosion inhibitors for aluminium in 0.1 M HCl. Corros. Sci., 51, $1868-1875$.

[18]. Oguzie, E. E.; Onuoha, G. N.; Onuchukwu, A. I., (2005), Inhibitory mechanism of mild steel corrosion in 2M sulphuric acid solution by methylene blue dye, Mater. Chem. Phys., 89 305-311.

[19]. Christov M., Popova A., (2004), Adsorption characteristics of corrosion inhibitors from corrosion rate measurements Corros. Sci., 46,1613

[20]. Ngobiri N.C, Oguzie E.E, Li Y, Liu L, Oforka N.C, and Akaranta O., (2015), Eco-Friendly Corrosion Inhibition of Pipeline Steel Using Brassica oleracea, International Journal of Corrosion, 10. 1155, 404139.

[21]. Abiola, O. K. (2005), Adsorption of methionine on mild steel. Journal of Chilean Chemical Society,50, 685-690

[22]. Ebenso, E.E., (2003). Synergistic effect of halide ions on the corrosion inhibition of aluminium in $\mathrm{H}_{2} \mathrm{SO}_{4}$ using 2acetylphenothiazine, Mater. Chem. and Phys., 79 (1): 58-70.

[23]. Buchweishaija, J. (2009) Phytochemicals as green corrosion inhibitors in various corrosive media: A Review. Tanz. J. Sci. 35:7792.

[24]. Ebenso E.E. (2004) Effect at methyl red and halide ions on the corrosion inhibition of aluminum in $\mathrm{H}_{2} \mathrm{SO}_{4}$. Part 2, Bull Electrochem, 20: 551-559.

[25]. Okigbo R.N. and Igwe D.I., (2007) Antinmicrobial effects of Piper guineense and phyllantus amarantus Ebe-benizo on candida albicans and streptococcus faecalis, Acta microbial immunal Hung, 54 (4) 353-66

[26]. Morufu E. B, Elizabeth E. B., Serges F. A . D, Ogochukwu S. M, Jacinta N. O., (2016) A Review of Piper guineense (African Black Pepper), Ijppr.Human, 6 (1): 368-384.

[27]. Uhegbu F.O, Chinedu I, and Amadike E.U (2015) Effect of Aqueous extract of Piper guineense seeds on some Liver enzymes, antioxidant enzymes and some Hematological Parameters in Albino rats. Intern J. plant Sci. Ecology, 1 (4): 167 - 171

[28]. Manta S, Saxena J, Nema R, Singh D and Gupta A (2013). Phytochemistry of medicinal plants. J. pharmacogphytochem, 1(6): 168182.

[29]. Klin Kabari D, Barimalaa I, Achinewhu S.C, Adeniji T.A (2011), Effects of extracts from 3 indigenous spices on the chemical stability of smoked dried catfish. (Clarias lazera) during storage. Afr. J. Food, Agric, Nutrition and Development, 11 (6): $72-85$ 
[30]. Adesokan, A.A and Akanji, M.A (2010), Antimalarial bioactivity of Enantia chloranthastembark. Medicinal plants: phytochem, pharmacol Therapeu 4 (1): 441 - 447.

[31]. Adegbola, J.D (1972), Molluscicidal properties of some African plants. J. parasitology, 107: 108-115 36.

[32]. Sumathykutty M.A, Rao J.M, Padmakumari K.P and Narayan C.S (1999). Essential oil constituents of some piper species, flavours fragrance Journal, 14: 280-281. 37.

[33]. Nwachukwu, C.U; Ume, N.C; Obasi, M.N; Nzewuihe, G.U and Onyirioha, .C (2010), The qualitative uses of some medicinal plants in Ikeduru LGA of Imo state, Nigeria, New York Science Journal,3 (11):132-129-134.

[34]. Ray J.D (1982). Epilepsy in China Lancet. Issue 1024: 205

[35]. Kupchan SM, Hemmnigway RJ, Karim A, Werner D., (1969),Tumor inhibitors. XLVII Vernodalin and Vernomygdin. Two new cytotoxic sesquiterpene lactones from Vernonia amygdalina Del. J. Org. Chem.;34:3908-3911

[36]. Moundipa F.P, Kamini G, Melanie F, Bilong FC, Bruchhaus I. (2000). In vitro amoebic activity of some medicinal plants of the Bamun region (Cameroon) Afr. J. Tad. Cam, 62:113-121.

[37]. Akah PA, Ekekwe R.K., (1995), Ethnopharmacology of some of the asteraceae family used in the Nigerian traditional medicine, Fitoterapia, 66:352-355.

[38]. Akinpelu D.A., (1999), Antimicrobial activity of Vernonia amygdalina leaves, Fitoterapia, 70:232-234

[39]. Hladik C, Krief S, Haxaire C., (2005) Ethnomedicinal and bioactive properties of plants ingested by wild chimpanzees in Uganda, J. Ethnopharmacol.101:1-5.

[40]. Muraina I.A, Adaudi A.O, Mamman M., Kazeem H.M, Picard J., McGaw LJ., Eloff J.N., (2010), Antimycoplasmal activity of some plant species from northern Nigeria compared to the currently used therapeutic agent. Pharm. Biol. 48:1103-1107

[41]. Cimanga R.K, Tona L, Mesia K, Musuamba CT, De Bruyne T, Apers S, Hernan N, Miert VS, Pieters L, Totte J, Vlietink AJ., (2004), In vitro antiplasmodia acivity of extravts and fractions of seven medicinal plants used in the democratic republic of Congo, J. Ethnopharmacol, 93:27-32.

[42]. Izevbigie EB., (2003), Discovery of water-soluble anticancer Agents (Edotides) from a vegetable found in Benin City, Nigeria, Exp. Biol. Med., 228:293-298.

[43]. Popova A. (2007) Temperature effect on mild steel corrosion in acid media in presence of azoles, Corros. Sci., 49:2144-2158

[44]. Khaled K.F., and Abdel .R., (2008),Electrochemical investigation of corrosion and corrosion inhibition of iron in hydrochloric acid solution, Mater. Chem. Phys., 112: 290-300

[45]. Ibisi N. E., Ngwamaghi V. I. and Okoroafor D. O. (2015), Eco-friendly corrosion inhibitors: Adsorption and inhibitive action of ethanol extracts of Mallotus oppositifolius leaves for the corrosion of mild steel in 1M Hydrochloric acid solution. Int. J. of Eng. and Sci. (THE IJES), 4, 7:31-37.

[46]. Ngobiri N.C, Akaranta O, Oforka N.C, Oguzie E.E, and Ogbulie S.U, (2013) "Inhibition of pseudo-anaerobic corrosion of oil pipelines water using biomas-derived molecules," Advances in Materials and Corrosion, . 2.. 20-25.

[47]. Okafor, P.C., and Ebenso, E.E., (2007). Inhibitive action of Carica papaya extracts on the corrosion of mild steel in acidic media and their adsorption characteristics. Pigment \& Resin Technology, 36(3): 134.

[48]. Ekpe, U.J., Ibok, U.J., Ita, B.I., Offiong, O.E., and Ebenso, E.E., (1995). Inhibitory action of methyl and phenyl thiosemicarbazone derivatives on the corrosion of mild steel in hydrochloric acid. Materials Chemistry and Physics, 40(2): 87.

[49]. Ita B. I., Offiong O. E, (1997) Inhibition of steel corrosion in HCl by pyridoxal-(4- methylthiosemicarbazide), pyridoxal-(4methylthiosemicarbazone) and its Zinc (II) complex, Mater. Chem. Phys., 48 (2) 164

[50]. Lukovists I., Kalman E., and Zuchi F., (2001), Corrosion inhibitors-correlation between electronic structure and efficiency, Corrosion Science, 57, 1, 3-8

[51]. Aramaki K. and Hackermann N. (1969), Inhibition mechanism of medium-sized polymethyleneimine, Journal of the Electrochemical Society, 116, 5, 568-574.

[52]. Ebenso E.E. and Ekpe U.J. (1996), Kinetic study of corrosion and corrosion inhibition of mild steel in $\mathrm{H}_{2} \mathrm{SO}_{4}$ using Carica papaya leaves extract W. Afric. J. Bio. Appl. Chem., 41 p. 21

[53]. Ebenso, E.E., Eddy, N.O and Odiongenyi, A.O., (2008), Corrosion inhibitive properties and adsorption behaviour of ethanol extract of Piper guinensis as a green corrosion inhibitor for mild steel in $\mathrm{H}_{2} \mathrm{SO}_{4}$. African Journal of Pure and Applied Chemistry, 2(11): $107-115$.

[54]. El-Etre, A.Y., Abdallah, M., and El-Tantawy, Z.E. (2005). Corrosion inhibition of some metals using lawsonia extract. Corrosion Science, 47 (2):385-395.

[55]. Ebenso, E.E. (2003b). Effect of halide ions on the corrosion. Inhibition of mild. Steel in $\mathrm{H}_{2} \mathrm{SO}_{4}$ using methyl red part 1, Bull Electrochem. 19: 209-216.

[56]. Douye V. Z., Elijah I. O., and Biobelemoye N. (2014), anti-microbial activity of ethanol extract of Senna alata leaves against some selected micro-organisms in Bayelsa state Nigeria, Greener Journal of Microbiology and anti-microbials 2(2), 026 - 031.

[57]. Ibisi N. E., Aguchime N. O. And Okoroafor D. O. (2015), Inhibitory effect of Alstonia congensis leaves and stem bark extracts on corrosion of mild steel in sacid medium, Int. J. of App. Res. and Tech. 4, 7: 138 - 146.

[58]. Ejikeme P.M., Umuna S.G., Meakiti M.C., Onukwuli O.D., (2015), Inhibition of mild Steel and Aluminium Corrosion in 1M $\mathrm{H}_{2} \mathrm{SO}_{4}$ by leaves Extract of African Breadfruit, Int. Journal of Material and Chemistry, 5(1):14-23

[59]. Ibisi N. E., and Anyanwu B., (2015), Costus afar extract as a sustainable inhibitor of mild steel corrosion in aggressive environment. International Journal of Applied Research and Technology 4(7): 110 - 117. 